\title{
Effective transfer of chromosomes carrying leaf rust resistance genes from Aegilops tauschii Coss. into hexaploid triticale ( $X$ Triticosecale Witt.) using Ae. tauschii $\times$ Secale cereale amphiploid forms
}

\author{
Michal Kwiatek • Maciej Majka • Halina Wiśniewska • \\ Barbara Apolinarska • Jolanta Belter
}

Received: 26 September 2014 / Revised: 23 November 2014 / Accepted: 2 December 2014 /Published online: 14 December 2014

(C) The Author(s) 2014. This article is published with open access at Springerlink.com

\begin{abstract}
This paper shows the results of effective uses of a molecular cytogenetics toolbox and molecular marker to transfer leaf rust resistance genes from Aegilops tauschii $\times$ Secale cereale (DDRR, $2 \mathrm{n}=4 \mathrm{x}=28$ ) amphiploid forms to triticale cv. Bogo (AABBRR, 2n=6x=42). The molecular markers of resistance genes and in situ hybridization analysis of mitotic metaphase of root meristems confirmed the stable inheritance of chromosome 3D segments carrying Lr32 from the $\mathrm{BC}_{2} \mathrm{~F}_{2}$ to the $\mathrm{BC}_{2} \mathrm{~F}_{5}$ generation of (Ae. tauschii $\times$ $S$. cereale $) \times$ triticale hybrids. The chromosome pairing analysis during metaphase $\mathrm{I}$ of meiosis of $\mathrm{BC}_{2} \mathrm{~F}_{4}$ and $\mathrm{BC}_{2} \mathrm{~F}_{5}$ hybrids showed increasing regular bivalent formation of $3 \mathrm{D}$ chromosome pairs and decreasing number of univalents in subsequent generations. The results indicate that using amphiploid forms as a bridge between wild and cultivated forms can be a successful technology to transfer the D-genome chromatin carrying leaf rust resistance genes into triticale.
\end{abstract}

Keywords Aegilops tauschii $\cdot$ Fluorescence and genomic in situ hybridization $\cdot$ Gene sources $\cdot$ Meiosis $\cdot$ Mitosis ·

Resistance genes markers · Triticale

\author{
Communicated by: Andrzej Górny \\ M. Kwiatek $(\bowtie) \cdot$ M. Majka $\cdot$ H. Wiśniewska $\cdot$ B. Apolinarska • \\ J. Belter \\ Institute of Plant Genetics, Polish Academy of Sciences, \\ Strzeszyńska 34, 60-479 Poznań, Poland \\ e-mail: mkwi@igr.poznan.pl \\ M. Majka \\ e-mail: mmaj@igr.poznan.pl \\ H. Wiśniewska \\ e-mail: hwis@igr.poznan.pl \\ J. Belter \\ e-mail: jbel@igr.poznan.pl
}

\section{Introduction}

Triticale ( $X$ Triticosecale Witt.) was created using wide crosses to combine the valuable traits of wheat (Triticum aestivum L.) and rye (Secale cereale L.) (Aase 1930; O’Mara 1953; Jenkins 1969; Kiss and Videki 1971). At first, diseases did not appear to be a serious limitation to triticale production, probably because the areas of production of this crop were not conductive to cause serious shifts in pathogen virulence (Singh and Saari 1991). When triticale began to expand into new production areas, new hybrid pathotypes carrying virulence genes appeared (Arseniuk 1996). The most common diseases of triticale are caused by fungal pathogens, such as leaf rust (caused by Puccinia triticina) and powdery mildew (caused by Blumeria graminis) (Singh and Saari 1991 and Troch et al. 2014, respectively). One of the main breeding strategies for triticale improvement was to introduce Dgenome chromosomes into $6 \mathrm{x}$ triticale (AABBRR). A number of efforts to produce triticale substitution lines were made. The simplest way to obtain $\mathrm{D}(\mathrm{A})$ or/and $\mathrm{D}(\mathrm{B})$ substitution lines is through octoploid (AABBDDRR) $\times$ tetraploid (AARR or BBRR) triticale crosses (Krowlow 1970; Lukaszewski et al. 1984; Apolinarska 1993). Another way to introduce Dchromosomes into triticale is using wild, diploid goatgrasses, which are ancestors carrying the D-genome, to create Aegilops tauschii Coss. $(\mathrm{DD}, 2 \mathrm{n}=2 \mathrm{x}=14) \times$ S. cereale $(\mathrm{RR}, 2 \mathrm{n}=2 \mathrm{x}=14)$ hybrids (Fedak 1984; Cabrera et al. 1996). Ae. tauschii has approximately 23,000 protein coding genes and 1,200 NBSLRR genes, which provides a large number of potential disease resistance loci (Jia et al. 2013). A number of resistance genes were transferred form Ae. tauschii to cultivated wheat. Resistance genes like $L r 21$ (on chromosome 1DS), $L r 22 a$ (2DS), Lr32 (3D), Lr39 (2DS), Lr40 (1DS), Lr42 (1D), and Lr43 (7DS) are the most essential for resistance durability 
(Rowland and Kerber 1974; Cox et al. 1994; Hussien et al. 1997; Raupp et al. 2001). However, the utilization of interspecific crosses between triticale and related species are arduous and prolonged because of genetic barriers of crossability controlled by $\mathrm{Kr}$ genes (Riley and Chapman 1967; Sitch et al. 1985; and Zheng et al. 1992, respectively). Moreover, the suppression of homologue chromosome pairing by the $\mathrm{Ph}$ genes may also interfere with the performance of distant crosses (Riley and Chapman 1958; Sears 1976; Lukaszewski and Kopecký 2010).

In this study, we have used the (Aegilops tauschii $\times$ $S$. cereale) $\times$ triticale hybrids, which were obtained by hybridization of the Aegilops tauschii $\times S$. cereale amphiploids (DDRR, $2 \mathrm{n}=4 \mathrm{x}=28$ chromosomes) with hexaploid triticale cv. Bogo as a paternal component to obtain the $\mathrm{F}_{1}$ generation of hybrids, which were, therefore, backcrossed with triticale 'Bogo' (pollinator) to obtain $\mathrm{BC}_{1} \mathrm{~F}_{1}$ and $\mathrm{BC}_{2} \mathrm{~F}_{1}$ hybrids, and further self-crossed to produce following generations $\left(\mathrm{BC}_{2} \mathrm{~F}_{2}\right.$ to $\mathrm{BC}_{2} \mathrm{~F}_{5}$; Fig. 1a). The Aegilops tauschii $\times$ S. cereale amphiploids, produced using embryo rescue by Sulinowski and Wojciechowska of the Institute of Plant Genetics, Polish
Academy of Sciences, Poznań, Poland (data unpublished), carried 28 chromosomes having Lr22a and Lr39 (Kwiatek et al. 2012) and Lr32 (data unpublished) markers connected with resistance to leaf rust. The aim of this study was: (1) to characterize the chromosome composition of the hybrids $\left(\mathrm{BC}_{2} \mathrm{~F}_{2}\right.$ to $\left.\mathrm{BC}_{2} \mathrm{~F}_{5}\right)$ of Ae.tauschii $\times$ triticale hybrids; (2) to identify the D-genome DNA markers which are linked with leaf rust resistance in the hybrids; and (3) to evaluate the stability of D-genome chromosomes inheritance by the chromosome pairing analysis during $\mathrm{MI}$ (metaphase I) of meiosis of pollen mother cells (PMCs) of $\mathrm{BC}_{2} \mathrm{~F}_{4}$ and $\mathrm{BC}_{2} \mathrm{~F}_{5}$ hybrids.

The chromosome preparations for FISH/GISH (fluorescence/genomic in situ hybridization) analysis were made according to Hasterok et al. (2006). The MI (first metaphase) of PMCs meiosis preparation of chromosomes for the GISH experiment were made according to Schubert et al. (2001). The identification of particular chromosomes was performed by comparing the signal pattern of $5 \mathrm{~S}$ rDNA, $25 \mathrm{~S}$ rDNA, pSc119.2, and pAs1 probes according to a previous study (Kwiatek et al. 2013) and similar cytogenetic analysis (Cuadrado and Jouve 1994; Schneider et al. 2003, 2005;
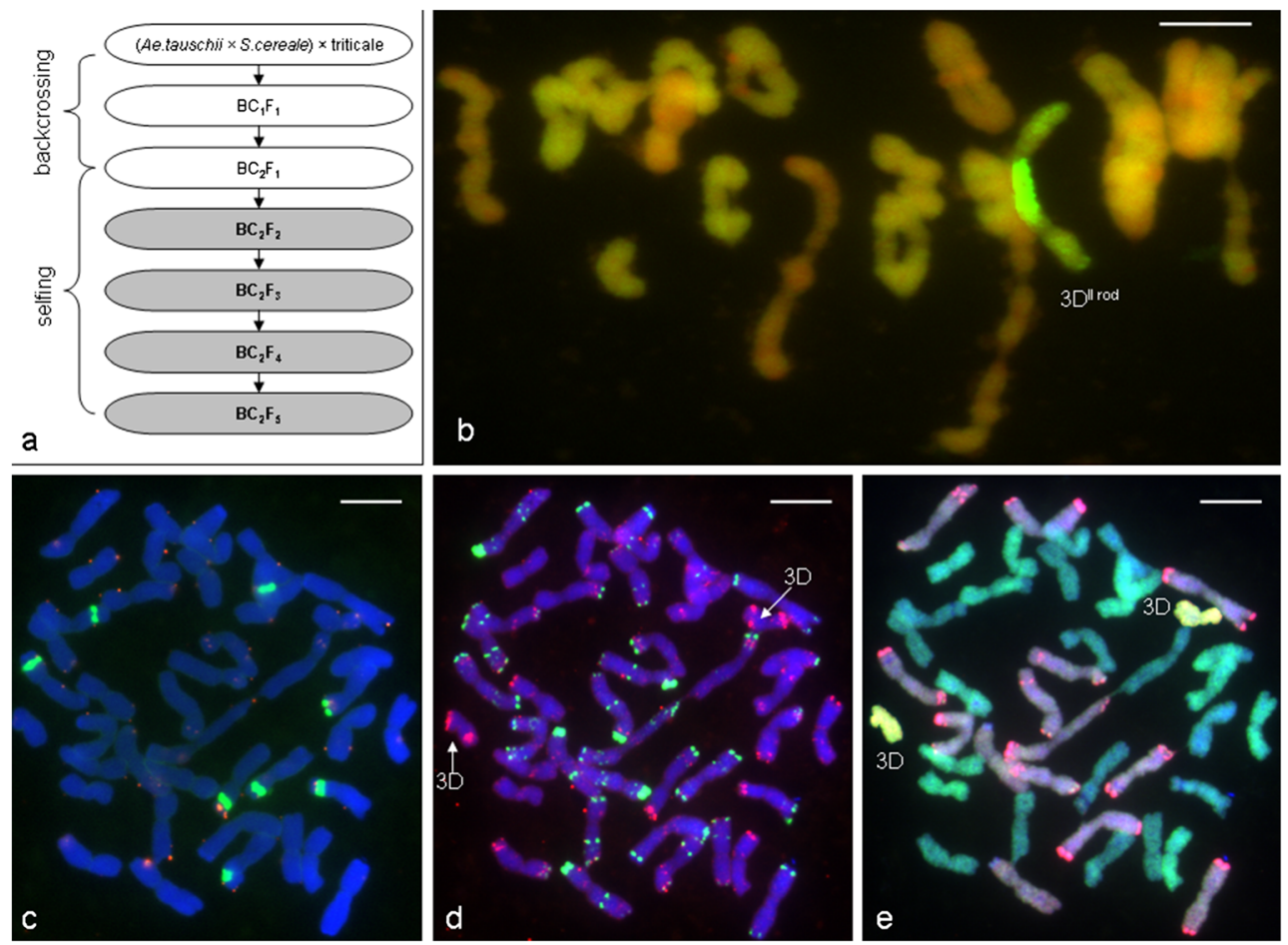

Fig. 1 a The scheme of subsequent crosses between Aegilops tauschii $\times$ Secale cereale amphiploid forms and triticale cv. Bogo. Hybrids from the generations on distinguished fields were evaluated. b Genomic in situ hybridization (GISH) discrimination of Ae. tauschii chromosomes labeled using digoxigenin-11-dUTP (green) and unlabeled triticale chromosomes (orange) on meiotic metaphase I chromosome spread of pollen mother cells (PMCs) from the $\mathrm{BC}_{2} \mathrm{~F}_{5}$ hybrid of (Aegilops tauschii $\times$ Secale cereale $) \times$ triticale, $20 "+1 " 3 \mathrm{D}(3 \mathrm{~B})$. c Fluorescence in situ hybridization (FISH) pattern showing the location of $5 \mathrm{~S}$ rDNA (red) and $35 \mathrm{~S}$ rDNA (green); d FISH pattern showing the location of
pSc119.2 (green) and pAs1 (red) repetitive clones; and e GISH with a total genomic DNA from rye, R-genome, labeled with rhodamine (red); total genomic DNA from Triticum monococcum, A-genome, labeled with digoxigenin and detected by anti-digoxigenin conjugated with FITC (green/yellow); and total genomic DNA from Aegilops tauschii, Dgenome, labeled with digoxigenin-11-dUTP and tetramethylrhodamine5-dUTP (ratio 1:1) with blocking genomic DNA of Aegilops speltoides, B-genome (DAPI, blue) on mitotic, the same chromosome spread of the $\mathrm{BC}_{2} \mathrm{~F}_{5}$ hybrid of (Aegilops tauschii $\times$ Secale cereale $) \times$ triticale 
Wiśniewska et al. 2013). Genomic DNA from Ae. tauschii (Dgenome), Triticum monococcum (A-genome), and Secale cereale (R-genome) was labeled by nick translation (using the Nick Translation Kit, Roche, Mannheim, Germany) with digoxigenin-11-dUTP (Roche) or tetramethyl-rhodamine-5dUTP (Roche), depending on the visualization concept. The 5S rDNA probe was generated from the wheat clone pTa794 (Gerlach and Dyer 1980) by polymerase chain reaction (PCR) amplification and labeled by PCR with tetramethylrhodamine-5-dUTP using universal M13 sequencing primers. The $25 \mathrm{~S}$ rDNA probe was made by nick translation of a 2.3-kb ClaI subclone of the 25S rDNA coding region of Arabidopsis thaliana (Unfried and Gruendler 1990) with digoxigenin-11-dUTP. The latter probe was used for the detection of $35 \mathrm{~S}$ rDNA loci. The pSc119.2 repetitive DNA sequence was amplified and labeled by PCR with digoxigenin-11-dUTP by using universal M13 primers (Vrána et al. 2000). The probe pAs1 was amplified by PCR from the genomic DNA of Ae. tauschii and labeled with digoxigenin-11-dUTP, according to Nagaki et al. (1995). Digoxigenin was detected using antidigoxigenin-rhodamine antibody (Roche). Chromosome and probe denaturation, hybridization, and post- hybridization washes were performed as described by Kwiatek et al. (2013). The identification of STS markers for Lr22a (Xgwm296), Lr32 (Xbarc135), and Lr39(Xgdm35) were made according to Hiebert et al. (2007), Thomas et al. (2010), and Pestsova et al. (2000), respectively).

\section{Results and discussion}

According to the literature, chromosome 2D of Ae. tauschii carries the Lr22a and Lr39 markers (Hiebert et al. 2007 and Pestsova et al. 2000, respectively) and chromosome 3D possess the Lr32 marker (Kerber 1987; Thomas et al. 2010) for leaf rust inheritance resistance genes. A sole plant exhibiting 46 chromosomes with two additional pairs of $2 \mathrm{D}$ and $3 \mathrm{D}$ chromosomes was chosen from $\mathrm{BC}_{2} \mathrm{~F}_{2}$ hybrids for the molecular analysis. The products of $L r 22 a$ primers amplification resulted in 135 base pairs (bp) and 167 bp bands, which are characteristic for susceptible genotypes, according Hiebert et al. (2007). The PCR reaction using Lr32 primers resulted in $261 \mathrm{bp}$ and $273 \mathrm{bp}$ products amplification, which indicate resistant genotypes. The $\operatorname{Lr} 39$ marker was also identified in this plant using PCR, which resulted in a 185 bp product, appropriate for resistant genotypes. This plant was selfcrossed to produce following generations $\left(\mathrm{BC}_{2} \mathrm{~F}_{3}\right.$ to $\left.\mathrm{BC}_{2} \mathrm{~F}_{5}\right)$ (Fig 1a). The chromosome composition of hybrid plants was similar as generations advanced. The analysis of the progeny showed that six plants of the $\mathrm{BC}_{2} \mathrm{~F}_{3}$ generation with addition of the pairs of 2D and 3D chromosomes also carried the $L r 32$ and $L r 39$ markers. Moreover, in four plants with additional 2D chromosome and four other plants with additional 3D chromosome, we have separately observed the amplification products for $L r 39$ and $L r 32$, respectively. The $\mathrm{BC}_{2} \mathrm{~F}_{4}$ plants were obtained from 21" + 1"3D+1"2D genotypes (Table 1; Fig. 2). Fifteen plants with an additional pair of 3D chromosomes

Table 1 Results of the identification of STS markers for leaf rust resistance $(L r)$ in triticale with the introgression of D-genome chromatin from Aegilops tauschii $\times$ S. cereale amphiploids

\begin{tabular}{|c|c|c|c|c|c|c|}
\hline \multirow[t]{2}{*}{ Hybrid generation } & \multicolumn{3}{|c|}{ Chromosome constitution of hybrids } & \multicolumn{3}{|c|}{$\begin{array}{l}\text { Number of plants carrying } L r \text { marker (number } \\
\text { of heterozygous plants) }\end{array}$} \\
\hline & Number of plants & Appearance of D-genome chromosome(s) & $2 n$ & $L r 22 a$ & $\operatorname{Lr} 32$ & $\operatorname{Lr} 39$ \\
\hline $\mathrm{BC}_{2} \mathrm{~F}_{2}$ & 1 & $1 " 3 \mathrm{D}+1 " 2 \mathrm{D} *$ & 46 & 0 & 1 & 1 \\
\hline \multirow[t]{4}{*}{$\mathrm{BC}_{2} \mathrm{~F}_{3}$} & 6 & $1 " 3 D+1 " 2 D$ & 46 & 0 & 6 & 6 \\
\hline & 4 & $1 ’ 2 D^{* *}$ & 43 & 0 & 0 & 4 \\
\hline & 4 & $1 ' 3 \mathrm{D}$ & 43 & 0 & 6 & 0 \\
\hline & 4 & 0 & 42 & 0 & 0 & 0 \\
\hline \multirow[t]{4}{*}{$\mathrm{BC}_{2} \mathrm{~F}_{4}$ from $21 "+1 " 2 \mathrm{D}+1 " 3 \mathrm{D}$} & 1 & $1 ’ 2 \mathrm{D}$ & 43 & 0 & 0 & 1 \\
\hline & 5 & $1 ’ 3 \mathrm{D}$ & 43 & 0 & 5 & 0 \\
\hline & 18 & $1 " 3 \mathrm{D}$ & 44 & 0 & 18 & $0(15)$ \\
\hline & 1 & 0 & 42 & 0 & 0 & 0 \\
\hline \multirow[t]{4}{*}{$\mathrm{BC}_{2} \mathrm{~F}_{5}$ from $21 "+1 " 3 \mathrm{D}$} & 3 & 1'3D & 43 & 0 & 3 & 0 \\
\hline & 34 & 1"3D & 44 & 0 & 34 & $0(34)$ \\
\hline & 12 & $1 " 3 \mathrm{D}(3 \mathrm{~B}) * * *$ & 42 & 0 & 12 & $0(12)$ \\
\hline & 2 & 0 & 42 & 0 & 0 & 0 \\
\hline
\end{tabular}

*Additional 2D chromosome pair and 3D chromosome pair

**Additional 2D chromosome

***Substitution pair 3D(3B) 


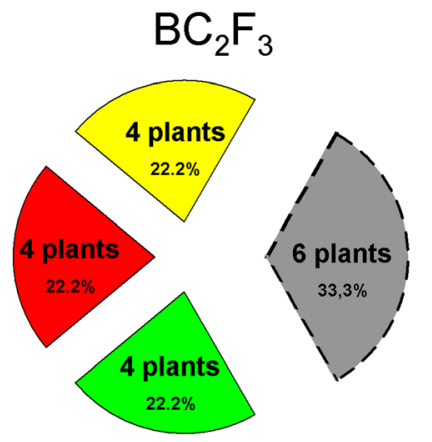

Fig. 2 Number of plants in subsequent generations of respective chromosome set groups as follows: $20 "+1$ " $3 \mathrm{D}+1$ " $2 \mathrm{D}(2 \mathrm{n}=46$; gray); $21 "+1$ '2D $(2 \mathrm{n}=43 ;$ yellow $) ; 21 "+1$ '3D $(2 \mathrm{n}=43 ;$ red $) ; 21 "+1 " 3 \mathrm{D}(2 \mathrm{n}=$

showed amplification products indicating heterozygosity (185 and 280 bp products; Pestsova et al. 2000) for the Lr39 marker, although the FISH experiment presented a lack of $2 \mathrm{D}$ chromosomes in these plants. The same situation appeared in all plants with an additional pair of 3D chromosomes (34 plants) and in 12 plants with substitution pair $3 \mathrm{D}(3 \mathrm{~B})$ of the $\mathrm{BC}_{2} \mathrm{~F}_{5}$ generation obtained from $21 "+1$ "3D genotypes (Table 1; Fig. 2).

It can be assumed that the high effectiveness of Dchromatin transfer from amphiploid forms (DDRR) into triticale (AABBRR) was caused by R-genome chromosomes pairing during prophase I of meiosis, which ensured the functional daughter cells formation. Moreover, the behavior of D-genome chromosomes studied during MI of meiosis of PMCs by GISH showed that the mean bivalent configurations increased when comparing $\mathrm{BC}_{2} \mathrm{~F}_{4}$ and $\mathrm{BC}_{2} \mathrm{~F}_{5}$ hybrids belonging to congruent plant groups divided with regard to the $\mathrm{D}$ genome chromosome configuration (Table 2). The increasing mean number of the bivalents was similar to the study of Orlovskaya et al. (2007), which showed that the bivalent appearance in $\mathrm{F}_{4}$ hybrid plants of triticale $\times$ (Aegilops $\times$
$\mathrm{BC}_{2} \mathrm{~F}_{4}$ $\mathrm{BC}_{2} \mathrm{~F}_{5}$
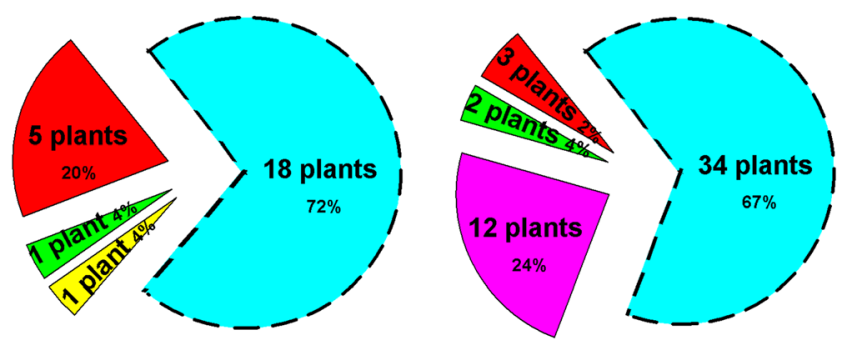

44; light blue); 20"+1'3D(3B) $(2 \mathrm{n}=42 ;$ pink $) ; 21 "+0 \mathrm{D}(2 \mathrm{n}=42 ;$ green $)$. The dotted line indicates plants selected for self-crosses to obtain the next generation of hybrids
Triticum aestivum; AABBUU and $\mathrm{AABBS} \mathrm{S}^{\text {sh }}{ }^{\text {sh }}$ ) was substantially higher than in the $\mathrm{F}_{1}$ hybrids. The mean number of Dgenome ring bivalents in the hybrids with an additional pair of $3 \mathrm{D}$ chromosomes (Table 2) was higher in $\mathrm{BC}_{2} \mathrm{~F}_{5}$ plants $(0.70)$ compared with $\mathrm{BC}_{2} \mathrm{~F}_{4}$ plants $(0.50)$. However, the mean number of $\mathrm{D}$-genome rod bivalents decreased from $0.45\left(\mathrm{BC}_{2} \mathrm{~F}_{4}\right)$ to $0.25\left(\mathrm{BC}_{2} \mathrm{~F}_{5}\right)$. On the other hand, considering the same groups of plants, the mean number of D-genome univalents decreased from 0.18 to 0.08 . According to the other studies concerning the meiotic analysis of Aegilops species with wheat and rye, the distant crosses should result in the intergenomic chromosome formation during meiosis. Molnár and Molnár-Láng (2010) observed the intergenomic rod and ring bivalents and trivalents between $2 \mathrm{M}, 3 \mathrm{M}, 3 \mathrm{U}$, and $7 \mathrm{M}$ of Ae. biuncialis and wheat (Chinese Spring phlb) chromosomes. In our study, we did not observe any intergenomic chromosome formation during meiosis. We suppose that triticale has the controlling system of homologue chromosome pairing that hampers the pairing of the chromosomes from different genomes. In wheat, homoeologous chromosome pairing and consequent recombination is suppressed

Table 2 Chromosome configurations during metaphase I (MI) of meiosis of pollen mother cells (PMCs) in (Aegilops tauschii $\times$ S. cereale) $\times$ triticale hybrids

\begin{tabular}{|c|c|c|c|c|c|c|c|c|c|c|c|c|c|c|}
\hline \multirow{4}{*}{$\begin{array}{l}\text { D-genome chromosome } \\
\text { configuration in hybrid } \\
\text { plants }\end{array}$} & \multirow{4}{*}{$\begin{array}{l}\text { Number of } \\
\text { PMCs studied }\end{array}$} & \multicolumn{9}{|c|}{ Mean number of bivalents } & \multirow{4}{*}{$\begin{array}{l}\text { Mean number } \\
\text { of quadrivalents } \\
\text { (RRRR) }\end{array}$} & \multicolumn{3}{|c|}{$\begin{array}{l}\text { Mean number } \\
\text { of univalents }\end{array}$} \\
\hline & & \multicolumn{8}{|c|}{ Mean number of bivalent configurations: } & \multirow[t]{3}{*}{ Total } & & & & \\
\hline & & \multicolumn{4}{|l|}{ Rods } & \multicolumn{4}{|l|}{ Rings } & & & & & \\
\hline & & Total & $\mathrm{AB} / \mathrm{AB}$ & $\mathrm{R} / \mathrm{R}$ & $\mathrm{D} / \mathrm{D}$ & Total & $\mathrm{AB} / \mathrm{AB}$ & $\mathrm{R} / \mathrm{R}$ & $\mathrm{D} / \mathrm{D}$ & & & $\mathrm{A} / \mathrm{B}$ & $\mathrm{R}$ & $\mathrm{D}$ \\
\hline \multicolumn{15}{|l|}{$\mathrm{BC}_{2} \mathrm{~F}_{4}$} \\
\hline $1 ' 2 \mathrm{D}$ & 40 & 4.50 & 4.15 & 0.35 & 0.00 & 16.30 & 9.65 & 6.65 & 0.00 & 20.80 & 0.00 & 2.10 & 0.00 & 0.95 \\
\hline 1 '3D & 40 & 6.80 & 5.45 & 1.35 & 0.00 & 12.80 & 7.50 & 5.30 & 0.00 & 19.60 & 0.05 & 1.85 & 0.00 & 0.95 \\
\hline $1 " 3 \mathrm{D}$ & 80 & 4.65 & 3.45 & 0.75 & 0.45 & 14.75 & 8.95 & 5.30 & 0.50 & 19.40 & 0.15 & 3.25 & 0.00 & 0.18 \\
\hline \multicolumn{15}{|l|}{$\mathrm{BC}_{2} \mathrm{~F}_{5}$} \\
\hline 1'3D & 40 & 7.56 & 6.33 & 1.23 & 0.00 & 12.96 & 7.18 & 5.78 & 0.00 & 20.52 & 0.00 & 2.00 & 0.00 & 0.98 \\
\hline 1"3D & 80 & 8.40 & 6.40 & 1.75 & 0.25 & 13.08 & 7.13 & 5.25 & 0.70 & 21.48 & 0.00 & 1.53 & 0.00 & 0.08 \\
\hline
\end{tabular}


by the function of the $P h 1$ gene (Riley and Chapman 1958), located on chromosome 5B(5BL), and the $P h 2$ gene on chromosome 3DS and 3AS (Mello-Sampayo 1971). The Chinese Spring ph1b (CSph1b) mutant genotype (Sears 1977), which lacks the $P h 1$ locus, has been successfully used for the introgression of alien genetic material into the wheat genome by the induction of homoeologous pairing (Lukaszewski 2000). This is the reason for the intergenomic bivalent and trivalent appearance in the study of Molnár and Molnár-Láng (2010). In this work, the rDNA-FISH analysis and repetitive sequence FISH experiments showed that the pair of chromosomes 5B was present in all hybrids examined (Fig. 1c, d). This consideration led us to suppose that triticale cv. Bogo and the $\mathrm{F}_{1}$ to $\mathrm{BC}_{2} \mathrm{~F}_{5}$ hybrids of $($ Ae. tauschii $\times S$. cereale $) \times$ triticale cv. Bogo could carry the dominant allele of the $P h 1$ gene. This assumption explained the appearance of 3D chromosomes in the following generations of hybrids, because only two homologue chromosomes can pair during meiosis and can be inherited from generation to generation.

The stable inheritance of $3 \mathrm{D}$ chromosome pairs from the $\mathrm{BC}_{2} \mathrm{~F}_{2}$ to $\mathrm{BC}_{2} \mathrm{~F}_{5}$ generations of (Ae. tauschii $\times$ S. cereale $) \times$ triticale hybrids can be considered as a successful attempt of D-genome introgression into triticale, without using deletion or mutation lines of wheat or triticale with lack of the whole Phl locus or Phla allele. The presence of the Lr32 marker in the $49 \mathrm{BC}_{2} \mathrm{~F}_{5}$ plants carrying $3 \mathrm{D}$ chromosomes (Fig. $1 \mathrm{~b}, \mathrm{c}, \mathrm{d}$, e) and the heterozygous character of the $46 \mathrm{BC}_{2} \mathrm{~F}_{5}$ plants considering the $L r 39$ marker makes them useful components in breeding programs aimed at triticale improvement.

Acknowledgments M.K., H.W., and B.A. initiated the project and designed the study. M.K., M.M., and J.B. performed the research. M.K. wrote the paper. We thank Dr. Marie Kubalakova (Laboratory of Molecular Cytogenetics and Cytometry, Institute of Experimental Botany, Olomouc, Czech Republic) for supplying us with pSc119.2 clones and for her valuable suggestions, and Dr. Tomasz Książczyk (Laboratory of Cytogenetics and Molecular Biology, Institute of Plant Genetics, Polish Academy of Sciences, Poznań, Poland) for supplying 5S and 25S rDNA sequences and for his clues. The technical assistance of Mrs. Grażyna Cicha and Mrs. Joanna Maszner is gratefully acknowledged.

This work was financed by the National Science Centre (DEC-2012/ 05/N/NZ9/01563).

Open Access This article is distributed under the terms of the Creative Commons Attribution License which permits any use, distribution, and reproduction in any medium, provided the original author(s) and the source are credited.

\section{References}

Aase HC (1930) Cytology of Triticum, Secale, and Aegilops hybrids with reference to phylogeny. Res Stud State Coll Wash 2:5-60

Apolinarska B (1993) Stabilization of ploidy and fertility level of tetraploid triticale obtained from four cross combinations. Genet Pol 34: $121-131$
Arseniuk E (1996) Triticale diseases - a review. In: Guedes-Pinto H, Darvey N, Carnide VP (eds) Triticale: today and tomorrow. Kluwer Academic Publishers, Dordrecht, pp 499-525

Cabrera A, Domínguez I, Rubiales D, Ballesteros J, Martín A (1996) Tetraploid triticale from Aegilops squarrosa L. $\times$ Secale L. spp. In: Guedes-Pinto H, Darvey N, Carnide VP (eds) Triticale: today and tomorrow. Kluwer Academic Publishers, Dordrecht, pp 179-182

Cox TS, Raupp WJ, Gill BS (1994) Leaf rust-resistance genes Lr41, Lr42, and Lr43 transferred from Triticum tauschii to common wheat. Crop Sci 34:339-343

Cuadrado A, Jouve N (1994) Mapping and organization of highlyrepeated DNA sequences by means of simultaneous and sequential FISH and C-banding in 6×-triticale. Chromosom Res 2:331-338

Fedak G (1984) Cytogenetics of tissue culture regenerated hybrids of Triticum tauschii $\times$ Secale cereale. Can J Genet Cytol 26:382-386

Gerlach WL, Dyer TA (1980) Sequence organization of the repeating units in the nucleus of wheat which contain $5 \mathrm{~S}$ rRNA genes. Nucleic Acids Res 11:4851-4865

Hasterok R, Dulawa J, Jenkins G, Leggett M, Langdon T (2006) Multisubstrate chromosome preparations for high throughput comparative FISH. BMC Biotechnol 6:20

Hiebert CW, Thomas JB, Somers DJ, McCallum BD, Fox SL (2007) Microsatellite mapping of adult-plant leaf rust resistance gene $\operatorname{Lr} 22 \mathrm{a}$ in wheat. Theor Appl Genet 115:877-884

Hussien T, Bowden RL, Gill BS, Cox TS (1997) Chromosome location of leaf rust resistance gene Lr43 from Aegilops tauschii in common wheat. Crop Sci 37:1764-1766

Jenkins BC (1969) History of the development of some presently promising hexaploid triticales. Wheat Inf Serv 78:18-20

Jia J, Zhao S, Kong X, Li Y, Zhao G, He W, Appels R, Pfeifer M, Tao Y, Zhang X, Jing R, Zhang C, Ma Y, Gao L, Gao C, Spannagl M, Mayer KF, Li D, Pan S, Zheng F, Hu Q, Xia X, Li J, Liang Q, Chen J, Wicker T, Gou C, Kuang H, He G, Luo Y, Keller B, Xia Q, Lu P, Wang J, Zou H, Zhang R, Xu J, Gao J, Middleton C, Quan Z, Liu G, Wang J; International Wheat Genome Sequencing Consortium, Yang H, Liu X, He Z, Mao L, Wang J (2013) Aegilops tauschii draft genome sequence reveals a gene repertoire for wheat adaptation. Nature 496:91-95

Kerber ER (1987) Resistance to leaf rust in hexaploid wheat: $\operatorname{Lr3} 2$ a third gene derived from Triticum tauschii. Crop Sci 27:204-206

Kiss A, Videki L (1971) Development of secondary hexaploid triticales by crossing triticale by rye. Wheat Inf Serv 32:17-20

Krowlow KD (1970) Untersuchungen über die Kreuzbarkeit zwischen Weizen und Roggen. Z Pflanzenzücht 64:44-72

Kwiatek M, Błaszczyk L, Wiśniewska H, Apolinarska B (2012) Aegilops-Secale amphiploids: chromosome categorisation, pollen viability and identification of fungal disease resistance genes. J Appl Genet 53:37-40

Kwiatek M, Wiśniewska H, Apolinarska B (2013) Cytogenetic analysis of Aegilops chromosomes, potentially usable in triticale (X Triticosecale Witt.) breeding. J Appl Genet 54:147-155

Lukaszewski AJ (2000) Manipulation of the 1RS.1BL translocation in wheat by induced homoeologous recombination. Crop Sci 40:216225

Lukaszewski AJ, Kopecký D (2010) The Phl locus from wheat controls meiotic chromosome pairing in autotetraploid rye (Secale cereale L.). Cytogenet Genome Res 129:117-123

Lukaszewski AJ, Apolinarska B, Gustafson JP, Krolow KD (1984) Chromosome constitution of tetraploid triticale. Z Pflanzenzücht 93:222-236

Mello-Sampayo T (1971) Genetic regulation of meiotic chromosome pairing by chromosome 3D of Triticum aestivum. Nat New Biol 230:22-23

Molnár I, Molnár-Láng M (2010) GISH reveals different levels of meiotic pairing with wheat for individual Aegilops biuncialis chromosomes. Biol Plant 54:259-264 
Nagaki K, Tsujimoto H, Isono K, Sasakuma T (1995) Molecular characterization of a tandem repeat, Afa family, and its distribution among Triticeae. Genome 38:479-486

O'Mara JG (1953) The cytogenetics of Triticale. Bot Rev 19:587-605

Orlovskaya OA, Kaminskaya LN, Khotyleva LV (2007) Introgression of Aegilops genetic material into the genome of hexaploid triticale. Russ J Genet 43:281-286

Pestsova E, Gana MW, Röder MS (2000) Isolation and mapping of microsatellite markers specific for the D genome of bread wheat. Genome 43:689-697

Raupp WJ, Sukhwinder-Singh, Brown-Guedira GL, Gill BS (2001) Cytogenetic and molecular mapping of the leaf rust resistance gene Lr39 in wheat. Theor Appl Genet 102:347-352

Riley R, Chapman V (1958) Genetic control of the cytological diploid behaviour of hexaploid wheat. Nature 182:713-715

Riley R, Chapman V (1967) Effect of 5Bs in suppressing the expression of altered dosage of $5 \mathrm{BL}$ on meiotic chromosome pairing in Triticum aestivum. Nature 216:60-62

Rowland GG, Kerber ER (1974) Telocentric mapping in hexaploid wheat of genes for leaf rust resistance and other characters derived from Aegilops squarrosa. Can J Genet Cytol 16:137-144

Schneider A, Linc G, Molnár-Láng M, Graner A (2003) Fluorescence in situ hybridization polymorphism using two repetitive DNA clones in different cultivars of wheat. Plant Breed 122:396-400

Schneider A, Linc G, Molnár I, Molnár-Lang M (2005) Molecular cytogenetic characterization of Aegilops biuncialis and its use for the identification of 5 derived wheat-Aegilops biuncialis disomic addition lines. Genome 48:1070-1082

Schubert I, Fransz PF, Fuchs J, de Jong JH (2001) Chromosome painting in plants. Methods Cell Sci 23:57-69
Sears ER (1976) Genetic control of chromosome pairing in wheat. Annu Rev Genet 10:31-51

Sears ER (1977) An induced mutant with homoeologous pairing in common wheat. Can J Genet Cytol 19:585-593

Singh RP, Saari EE (1991) Biotic stresses in triticale. In: Proceedings of the 2nd International Triticale Symposium, Passo Fundo, Rio Grande do Sul, Brazil, October 1-5, 1990. CIMMYT, Mexico, DF, pp 171-181

Sitch LA, Snape JW, Firman SJ (1985) Intrachromosomal mapping of crossability genes in wheat (Triticum aestivum). Theor Appl Genet 70:309-314

Thomas J, Nilmalgoda S, Hiebert C, McCallum B, Humphreys G, DePauw R (2010) Genetic markers and leaf rust resistance of the wheat gene Lr32. Crop Sci 50:2310-2317

Troch V, Audenaert K, Vanheule A, Bekaert B, Höfte M, Haesaert G (2014) The importance of non-penetrated papillae formation in the resistance response of triticale to powdery mildew (Blumeria graminis). Plant Pathol 63:129-139

Unfried I, Gruendler P (1990) Nucleotide sequence of the 5.8S and 25S rRNA genes and of the internal transcribed spacers from Arabidopsis thaliana. Nucleic Acids Res 18:4011

Vrána J, Kubaláková M, Simková H, Č́íhalíková J, Lysák MA, Dolezel J (2000) Flow sorting of mitotic chromosomes in common wheat (Triticum aestivum L.). Genetics 156:2033-2041

Wiśniewska H, Kwiatek M, Kulak-Książczyk S, Apolinarska B (2013) Introgression of A- and B-genome of tetraploid triticale chromatin into tetraploid rye. J Appl Genet 54:435-440

Zheng YL, Luo MC, Yen C, Yang JL (1992) Chromosome location of a new crossability gene in common wheat. Wheat Inf Serv $75: 36-40$ 